\title{
COMPARATIVE ANALYSIS OF SOCIAL SERVICES PROVIDED TO FEMALE COMBATANTS AND VETERANS IN UKRAINE AND ABROAD
}

\author{
Olena Faidiuk \\ Borys Grinchenko Kyiv University, Ukraine \\ Tetiana Liakh \\ Borys Grinchenko Kyiv University, Ukraine
}

\begin{abstract}
The war in Eastern Ukraine has been going on since 2014. This situation has led to new challenges for the social sphere, in particular, the construction of a system of social services for combatants and veterans. Female combatants and veterans need gender-specific services adopted to this particular category. Since the experience of social assistance to this specific category of clients of social work in Ukraine is limited, there is a need to study the experience of other countries to address the issue.

The purpose of the article is to analyze the peculiarities of women's military service and the system of social protection of this category in Ukraine and abroad.

The article analyzes the experience of Australia, Israel, Spain, Canada, Korea, Poland, the USA, and Croatia in implementing the policy of social protection of combatants. The authors identify the main types of services and assistance to this category provided by the legislation in other countries.

The authors of the article used the method of theoretical analysis of scientific works and legal documents that describe and regulate the mechanism of social protection of servicemen/servicewoman in different countries; compare the key aspects and features of women's military service in different countries and systematize the list of social services and structures responsible for providing various social services.

Keywords: female combatants; female veterans; social services to veterans; social protection; military social work; military service; serviceman/servicewoman; women serving in the army; social assistance.
\end{abstract}

\section{Introduction}

In the period from 2014 to the present, the fighting caused by the aggression of the Russian Federation is going on in Ukraine. These events have led to the emergence of a new facility for domestic social work - combatants in need of social assistance and support

This category of social services recipients is characterized by a change in the orientation of values, dissatisfaction with the new social and professional status, violations of social interaction and loss of interest in public life, reduced 
Faidiuk \& Liakh, 2021. Comparative Analysis of Social Services Provided to Female Combatants and Veterans in Ukraine and Abroad

activity, and the desire for social isolation. The adaptation of combatants to civilian life is accompanied by feelings of frustration, isolation, and alienation from public life because in real life their experience and knowledge are often not needed by civilians in communities.

According to the Ministry of Veterans of Ukraine, Temporarily Occupied Territories and Internally Displaced Persons, there were about 370,000 veterans in Ukraine in 2019 (Texty.Org.Ua, 2019). Approximately 29,760 women are serving in the Armed Forces of Ukraine, among the total number of 255,000 people, of which 902 are senior officers. Women serve in the National Guard of Ukraine, the State Border Guard Service of Ukraine, the Security Service of Ukraine, and the National Police. 9,136 women are participants in hostilities according to data on March 2020 (Ministerstvo oborony Ukrayiny, 2020).

Analysis of international experience, best practices, and approaches to social protection of servicemen is extremely important while developing an effective system of social protection for veteran women in Ukraine and provide them with integrated social services. The article analyzes the experience of Australia, Israel, Spain, Canada, Korea, Poland, the USA, and Croatia in implementing the policy of social protection of combatants. The authors identify the main types of services and assistance to this category provided by the legislation in other countries.

\section{Literature Review}

A large part of Ukrainian society is convinced that military affairs are only for men. However, contrary to all stereotypes, with the beginning of hostilities on the territory of Ukraine, we could see that women are ready to serve their country faithfully.

Social work with combatants and the provision of social services are regulated by the following legal documents: laws of Ukraine "On Improving the Financial Situation of Combatants and War Invalids" (Zakon Ukrainy № 1603IV, 2018), "On Social and Legal Protection of Servicemen and Members of their Families" (Zakon Ukrainy № 2011-XII, 2020), "On State Social Assistance to Low-Income Families" (Zakon Ukrainy № 1768-III, 2020), "On the Status of War Veterans, Guarantees of their Social Protection" (Zakon Ukrainy № 3551XII, 2020), "On Social Services" (Zakon Ukrainy № 2671-VIII, 2019), the resolution of the Cabinet of Ministers of Ukraine "On Approval of the Procedure for Granting Combatant Status to Persons Who Defended Independence, Sovereignty and Territorial Integrity of Ukraine and Took a Direct Part in the Anti-Terrorist Operation, Ensuring its Implementation" (Kabinet Ministriv Ukraini, 2014) and others. 
The issue of providing support and assistance to combatants, including women, is particularly relevant. After analyzing the data of opinion polls ("Invisible Battalion": women's participation in hostilities in the ATO (ICF "Ukrainian Women's Fund") (Martseniuk, Hrytsenko, \& Kvit, 2016); "Life after the conflict: Survey on socio-demographic and socio-economic characteristics of conflict veterans in eastern Ukraine and their families" (Predstavnytstvo MOM v Ukraini, 2020), it should be noted that the needs and requests of women are significantly different from the requests of men.

However, the formation and implementation of social protection policy on combatants are more focused on men than women (Dulia, Liakh, \& Veretenko, 2020). But it is important to understand that women who are involved in hostilities do have special needs, different from other categories of population, that need to be taken into account when providing social support and assistance.

Interestingly, in many countries, the duty to provide professional assistance to such categories of the population as servicemen and war veterans is performed by military social workers (there is even a special area of work military social work). Besides, there are certain features and restrictions of military service for women and mandatory social guarantees in different countries of the world. Unfortunately, there are no specially trained specialists in Ukraine to work with servicemen and combatants, while providing qualified assistance remains one of the important tasks of our country.

Therefore, it is extremely important to study the experience of foreign countries in providing social guarantees and providing social support to womenparticipants in hostilities.

\section{Methodology}

To achieve the goals of this study, the theoretical analysis of the scientific literature and Internet sources was used, which allowed to find out features of military service by women and to analyze the social protection system of servicemen in different countries of the world.

\section{Research Results}

From ancient times, a woman has performed more than just the role of a housewife throughout her life. In different historical periods, with the emergence of new social challenges (raids, strikes, demonstrations, wars, revolutions), women tried to be successful in various spheres of life and professional activity. The military sphere, which was quite successfully mastered by women, was no exception. The war in many countries of the world contributed to the 
Faidiuk \& Liakh, 2021. Comparative Analysis of Social Services Provided to Female Combatants and Veterans in Ukraine and Abroad

emancipation of women, they have gained new experience, new skills and abilities during these times.The war was a serious ordeal for the citizens of many warring countries, but todaysome countries still provide training for women in the military. Among such countries are Canada, Great Britain, the USA, Norway, Israel, North Korea, Malaysia, and some other countries. It was in these countries that women first began to take part in hostilities on an equal footing with men, not just as a nurse, cook, volunteer, or other. In these countries, military service is a woman's duty, and the countries have a large number of women in combat units. It was in these countries that the first women's military movements and groups emerged, which supported and protected the equal rights of women with other segments of the population.

For the first time in the world, women became full-fledged servicewomen with the appropriate status in Canada, in 1895. They were recruited for military service in peacetime not only in the support structure but also in combat units. Adoption in Canada in 1985 Human Rights Act contributed to the situation that $75 \%$ of military specialties became available to women. Great Britain is also thehomeland of the feminized army. In 1653, the first women's military hospitals appeared there, designed for 350 wounded (Androsenko, 2009).

It turns out that among European countries, women are required to serve in the army only in Norway. In general, the list of these countries is not too long. It includes Israel, North Korea, and Malaysia (Espreso.Tv, 2015). In most European and other countries of the world, the service of women in the army is based on a completely voluntary basis.

In Norway, from January 1, 2015, girls are required to serve in the army. By law, the Norwegian Armed Forces have conscription, it is a 19-month service obligation, but in fact, it rarely exceeds 12 months. Norway became the first country in Europe to oblige women to serve in the army. An important task of the Norwegian Armed Forces by 2020 is to increase the proportion of female commanders up to $20 \%$ of the total number of military personnel. According to Norwegian Army Chief of Staff I. Gierdeu, there are no special quotas for women in the Armed Forces of the Kingdom; however, almost 27\% of Norwegians are currently serving in the military (Poltavets, 2018).

Israel is one of the most developed countries in the world in terms of gender equality. According to the current legislation of the country, women have equalrights with men to chooseanymilitary occupation. However, this does not apply to everyone. If a girl is married before it is time to go to serve, she will not be drafted into the military. Also, a woman may refuse to serve in the army for religious or ethical reasons. About a third of women are exempted for health reasons, pregnancy, or religious grounds. 
The women drafted into the military service have several differences compared to men. First, the term of military service for men is 3 years and 21 months for women.

Women are allowed to leave the place of service for the night and return home, they are given benefits when entering the university and they are paid a substantial salary for their service. In less than two years, a servicewoman gets a certain profession depending on the military service she was in (Golan, 1997).

In North Korea, women also serve on an equal footing with men. In 2003, a law was passed setting the term of service for conscription: up to 10 years for men and up to 7 years for women.

Women began serving in the army in 1995, and the peak came in 1997. Then a terrible famine broke out in North Korea, and many young women joined the army voluntarily, knowing that they would at least be fed there. In a fact, military service is considered very prestigious today. Thus, not every Korean woman is drafted into the armed forces. To be accepted a young woman with good background must proveher loyalty to the party.

The particularly large numbers of women are typical of anti-aircraft troops and coastal artillery. In total, more than $10 \%$ of the Korean military personnel are servicewomen (Mota, Medved, Hiebert-Murphy, Whitney \& Sareen, 2018).

In Malaysia, women have the equal right to serve in the army. The service term is three months both for men and women. Besides, a woman can, along with a man, join the ranks of contractors, which is considered very prestigious in Malaysia (Poltavets, 2018).

The issue of equal rights and opportunities for women and men in military service in Ukraine is regulated by legislation. According to Ukrainian law, women have the right to serve in the military on an equal basis with men, to hold military positions, and to receive military ranks. However, the realities indicate that there are some differences between the defined norms and the implementation of these standards in practice.

No less important is the issue of social protection of servicemen. What benefits are provided? What kind of assistance can be expected? What guarantees are mandatory? It is worth noting that each country has its system of social protection for military servicemen.

Let's examine the different approaches in the organization and implementation of social protection of military personnel in different countries. The primary analysis shows that each country attempts to provide all the necessary services comprehensively, but the approach to providing this assistance is different.

The United States Department of Veterans Affairs (VA) is States is the second-largest body in the US federal government with more than 340,000 civil 
Faidiuk \& Liakh, 2021. Comparative Analysis of Social Services Provided to Female Combatants and Veterans in Ukraine and Abroad

servants and employees at the beginning of 2019. The Department has three main subdivisions, known as Administrations: Veterans Health Administration; Veterans Benefits Administration; National Cemetery Administration (EBenefits; The official site of the U.S.). The primary function of the Ministry is to support veterans by providing certain benefits, services, and social programs (Husak \& Neskorodiana, 2016). In the United States, there is no separate legal document that defines the social and legal protection of veterans, as in Ukraine.The main activities of the Ministry of Veterans Affairs include pensions; life insurance; vocational rehabilitation and employment; medical rehabilitation and care; registration of mortgage loans (housing loans); other benefits and allowances (in case of disability or loss of a breadwinner, burial benefits, and other). The main feature of providing social protection for servicemen in the United States is an extensive system of different areas of work with this target audience, which provides simple (one-time) and comprehensive services. The coordination of each direction is carried out by the relevant structural unit, which has its specifics of work. Also, in the United States, there is a special type of work with servicemen. Military social work is a specialized field of practice that provides qualified assistance and support (El-Gabalawy, Blaney, Tsai, Sumner \& Pietrzak, 2018).

The Republic of Poland provides the appropriate level and mechanism of social protection of servicemen, as it has an extensive system of entities that provide social and other services (Shkuropatskyi, 2016).

According to the Law of the Republic of Poland "On Provision of Military and Military Invalids and Members of Their Families", the amount, the procedure of calculation and assisting, as well as benefits for servicemen who received a disability during military service and for family members of invalids and servicemen if they were killed or missing in action in military operations. Veterans who participated in military operations outside the country have the right and opportunity to receive comprehensive support from the state (psychological assistance, discounts on medications, medical services, transportation, education, and others). The feature of the social protection of servicemen in Poland is providing different social benefits guaranteed by law, and the serviceman receives these benefits without fail.

In Spain, the state institutions take care of the affairs of war veterans and retired servicemen. The Spanish Ministry of Defense monitors information on the needs and requests of the target audience through the activities of nongovernmental organizations. In this state, servicemen who participated in peacekeeping operations are paid insurance compensation, the amount of which depends on the negative consequences of such participation (injury, disability, death). The social protection for military servicemen in Spain focuses on 
studying the needs and requests of the target audience to expand the network of quality services to meet the needs of servicemen (Beckie, Duffy, Groer, 2016).

Veterans of the war in Croatia are entitled to compulsory health insurance, pensions, disability benefits, child benefits, work, housing, psychological support (Hordiienko, 2020). Veterans are provided with a wide range of social benefits and guarantees: double length of service, minimum pension, payment of scholarships and tuition fees, free shares in companies, one-time annual financial assistance, vocational rehabilitation, housing loan, medical and psychological rehabilitation, and other (Berdak, 2015).

In Australia, the functional body is the Veterans Advisory Council, which aims to provide informational and psychological support. The social protection system of servicemen is focused mainly on the provision of medical services and rehabilitation (Gunter, O'Toole, Dadds, \& Catts, 2020).

In Israel, there is the Families and Commemoration Department. The main tasks of this Department are social protection, registration of social benefits, treatment, rehabilitation, and psychological support. To ensure the social and psychological well-being of the Israeli Defense Forces, the Association for the Wellbeing of Israel's Soldiers (AWIS) has been established to promote the wellbeing of soldiers in the areas of recreation, education, and culture.

Also, in 1981, the organization Friends of the Israel Defense Forces (FIDF) was established to ensure the personal well-being of servicemen (FIFD, n.d.).

The Ministry of Patriots and Veterans Affairs (MPVA) of South Korea provides support and health care, benefits, and national merit recognition (Kim \& Kim, 2019).

The Military Family Services Program (MFSP) in Canada is the Armed Forces-wide community-based support program delivering coordinated, consistent national services for families across the country through military family resource centers, as well as a framework for families and communities (Canadian Forces, n. d.). A military family is understood to be all Canadian Armed Forces personnel, their spouses, children, parents, and relatives (Belliveau, Cook, McLean, \& Lea, 2019).

The program of services for military families includes three blocks: 1) information and training; 2) support and services; 3) assistance and interventions. Besides, Canada has a practice of providing assisting and supporting servicemen and their families through information web portals, closed groups on social networks, and electronic and telephone counseling (MyVoice, Family information line FamilyForce.ca). Military Family Resource Centres (Canadian Forces, n.d.) provide information and educational activities, implement family programs, referrals, and short-term 249ounseling. MFRC ensure connecting military families to a wide range of programs and services. 
Faidiuk \& Liakh, 2021. Comparative Analysis of Social Services Provided to Female Combatants and Veterans in Ukraine and Abroad

Their goal is to build strong, resilient individuals, families and communities. There are 32 such Centers in Canada.

Based on the analysis of different approaches to the social protection system of servicemen in different countries, we have identified the main types of services in each mentioned above countries.

\begin{tabular}{|c|c|c|c|c|c|}
\hline USA & Poland & Spain & Croatia & \multirow{4}{*}{ 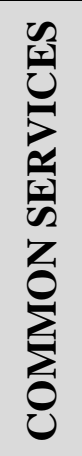 } & Medical care \\
\hline Insurance & $\begin{array}{l}\text { Professional } \\
\text { retraining }\end{array}$ & Financial aid & $\begin{array}{c}\text { Social } \\
\text { benefits }\end{array}$ & & Legal aid \\
\hline Canada & Australia & South Korea & Israel & & $\begin{array}{c}\text { Social } \\
\text { adaptation }\end{array}$ \\
\hline $\begin{array}{c}\text { Family } \\
\text { Resource } \\
\text { Centres }\end{array}$ & $\begin{array}{l}\text { Professional } \\
\text { rehabilitation }\end{array}$ & $\begin{array}{l}\text { National } \\
\text { merit }\end{array}$ & $\begin{array}{c}\text { Personal } \\
\text { well-being }\end{array}$ & & $\begin{array}{c}\text { Psychological } \\
\text { assistance }\end{array}$ \\
\hline
\end{tabular}

Figure 1 Social Protection of Combatants in Foreign Countries

(compiled by the author based on data analysis)

\section{Conclusions and Recommendations}

Nowadays, the issue of military service by women and men is not new, but it has several features and problematic aspects that need attention and solutions. Based on the analysis of the international and domestic experience of social protection of servicemen it was found that the mechanism for providing services for such category as women-combats isn't established. It should be noted that conditions in normative legal acts, the main tasks of gender policy, which are embodied in real practice are not always clearly defined. Coming home after military service is an important stage in the new adaptation to the living conditions of the "here and now". The provision of professional assistance and support to servicemen should be based on such principles as focus on the individuality of a person with his/her specific needs, mental state and moral guidelines; integration, which allows combining the practice of serving a particular client with the conditions of the real social environment; holistic approach to the client as a person with his or her worldview, moral and mental state, ideological values; the principle of self-help, which involves the activation of the client's forces to promote effective social functioning.

The application of successful experience of different countries in the formation, organization and implementation of the mechanisms of social protection of servicemen, combatants, war veterans (including women combatants) should be based on the needs and demands of the target audience in 
the country. The following studies of topical issues that meet the realities and requirements of today's Ukraine should be carried out.

\section{Acknowledgments}

The study was conducted in the framework of the scientific theme of the Institute of Human Sciences of Borys Grinchenko Kyiv University "Personality in conditions of social transformations of modern Ukraine", registration number: 0116U002960, deadline - 5.2016-5.2021.

\section{References}

Androsenko, I. (2009). Aty-baty, yshly...divchata, abo istorychnyi ekskurs shchodo gendernoi polityky $\mathrm{v}$ zbroinykh sylakh providnykh krain svitu. Ynformatsyonnoprosvetytelskoe yzdanye «Ya», 31-32. http://krona.org.ua/assets/files/journal/ Gendernyi-zhurnal-Ya-roli.pdf

Beckie, T. M., Duffy, A., \& Groer, M. W. (2016). The relationship between allostatic load and psychosocial characteristics among women veterans. Women's Health Issues, 26(5), 555-563. https://doi.org/10.1016/j.whi.2016.05.008

Belliveau, G., Cook, C., McLean, B., \& Lea, G. W. (2019). Thawing out: Therapy through theatre with Canadian military veterans. The Arts in Psychotherapy, 62, 4551. https://doi.org/10.1016/j.aip.2018.11.001

Berdak, O. (2015). Reintegrating veterans in Bosnia and Herzegovina and Croatia: Citizenship and gender effects. Women's Studies International Forum, 49, 4856. https://doi.org/10.1016/j.wsif.2014.07.001

Canadian Forces. (n.d.). Military Family Resource Centres (MFRC). Retrieved from: https://www.cafconnection.ca/National/Programs-Services/Deployment-Support/ Deployment-Support-for-Families/Military-Family-Resource-Centres-(MFRC).aspx

Dulia, A., Liakh, T., \& Veretenko, T. (2020). Types of families of joint forces operation participants in the east of Ukraine and peculiarities of social work with them. Society. Integration. Education. Proceedings of the International Scientific Conference, 4, 211. https://doi.org/10.17770/sie2020vol4.5106

El-Gabalawy, R., Blaney, C., Tsai, J., Sumner, J. A., \& Pietrzak, R. H. (2018). Physical health conditions associated with full and subthreshold PTSD in U.S. military veterans: Results from the National Health and Resilience in Veterans Study. Journal of Affective Disorders, 227, 849-853. https://doi.org/10.1016/j.jad.2017.11.058

Espreso.Tv. (2015). V yakykh krainakh svitu ta yak zhinky nesut viiskovu sluzhbu. Retrieved from: https://espreso.tv/article/2015/01/15/v_yakykh_krayinakh_svitu_ta_yak_zhinky_ nesut_viyskovu_sluzhbu

FIDF. (n.d.). Friends of the Israel Defense Forces. Homepage | Friends of the Israel Defense Forces. https://www.fidf.org/

Golan, G. (1997). Militarization and gender: The Israeli experience. Women's Studies International Forum, 20(5-6), 581-586. https://doi.org/10.1016/s0277-5395(97)00063-0

Gunter, H. N., O'Toole, B. I., Dadds, M. M., \& Catts, S. V. (2020). Family emotional climate in childhood and risk of PTSD in adult children of Australian Vietnam 
Faidiuk \& Liakh, 2021. Comparative Analysis of Social Services Provided to Female Combatants and Veterans in Ukraine and Abroad

veterans. Psychiatry Research, 294, 113509. DOI: https://doi.org/10.1016/ j.psychres.2020.113509

Hordiienko, Y. (2020). Svitovyi dosvid formuvannia ta realizatsii polityky sotsialnoho zakhystu uchasnykiv boiovykh dii. Visnyk Natsionalnoi akademii derzhavnoho upravlinnia pry Prezydentovi Ukrainy, 1(96), 86-94. DOI: https://doi.org/ 10.36030/2310-2837-1(96)-2020-86-94

Husak, N., \& Neskorodiana, O. (2016). Viiskovi sotsialni pratsivnyky u SShA. Naukovi zapysky NaUKMA. Retrieved from: http://ekmair.ukma.edu.ua/bitstream/handle/ 123456789/10817/Husak_Neskorodiana_Viiskovi_sotsialni_pratsivnyky.pdf?sequence= 1\&isAllowed=y

Kabinet Ministriv Ukraini. (2014). Pro zatverdzhennia Poriadku nadannia statusu uchasnyka boiovykh dii osobam, yaki zakhyshchaly nezalezhnist, suverenitet ta terytorialnu tsilisnist Ukrainy $i$ braly bezposeredniu uchast $v$ antyterorystychnii operatsii, zabezpechenni yii provedennia, Postanova № 413. Retrieved from: https://zakon.rada.gov.ua/laws/show/413-2014-п\#Text

Kim, S. W., \& Kim, H. C. (2019). The veterans experience, depression, and quality of life in elderly patients of a Korean veteran's hospital. European Neuropsychopharmacology, 29, 220-221. https://doi.org/10.1016/j.euroneuro.2018.11.359

Martseniuk, T., Hrytsenko, H., \& Kvit, A. (2016). «Nevydymyi batalion»: uchast zhinok u viiskovykh diiakh $v$ ATO (sotsiolohichne doslidzhennia) FOP Klymenko. http://ekmair.ukma.edu.ua/bitstream/handle/123456789/7746/Martsenyuk_Nevydymyi_ bataloin.pdf?sequence $=3 \&$ amp;isAllowed $=\mathrm{y}$

Ministerstvo oborony Ukrayiny. (2020). Nyni u viys'ku sluzhyt' mayzhe 30 tysyach zhinok. https://www.mil.gov.ua/diyalnist/genderni-pitannya-u-sferi-bezpeki/nini-u-vijskusluzhit-majzhe-30-tisyach-zhinok.html

Mota, N. P., Medved, M., Hiebert-Murphy, D., Whitney, D., \& Sareen, J. (2018). Negotiating home base: Narratives of psychological well-being among female military members. Health \& Place, 50, 105-111. https://doi.org/10.1016/j.healthplace. 2018.01.005

Poltavets, T. (2018). Nasha syla - u nashii slabkosti: Zakon pro hendernu rivnist cholovikiv ta zhinok u Zbroinykh sylakh Ukrainy. Hromadska dumka pro pravotvorennia, 160(16), 10-15. http://nbuviap.gov.ua/images/dumka/2018/16.pdf

Predstavnytstvo MOM v Ukraini. (2020). Zhyttia pislia konfliktu: Opytuvannia shchodo sotsialno-demohrafichnykh ta sotsialno-ekonomichnykh kharakterystyk veteraniv konfliktu na skhodi Ukrainy ta yikhnikh simei... https://iom.org.ua/sites/default/ files/veterans_reintegration_survey_2020_ukr.pdf

Shkuropatskyi, O. (2016). Svitovyi dosvid administratyvno-pravovoho rehuliuvannia sotsialnoho zakhystu ofitserskoho skladu Zbroinykh syl Ukrainy. Visnyk Kharkivskoho natsionalnoho universytetu imeni V. N. Karazina, (22), 118-122. https://periodicals. karazin.ua/law/article/view/9658

Texty.Org.Ua. (2019). Skil'ky v Ukrayini veteraniv ATO y vid yakykh vidomstv? (INFOHRAFIKA). Retrieved from: https://texty.org.ua/fragments/97005/Skilky_v_ Ukrajini_veteraniv_ATO_j_vid-97005/

Verhovna Rada Ukrainy. (2020). Zakon Ukrainy № 1768-III Pro derzhavnu sotsialnu dopomohu malozabezpechenym simiam. Retrieved from: https://zakon.rada.gov.ua/ laws/show/1768-14\#Text 
Verhovna Rada Ukrainy. (2018). Zakon Ukrainy № 1603-IV Pro polipshennia materialnoho stanovyshcha uchasnykiv boiovykh dii ta osib z invalidnistiu vnaslidok viiny. Retrieved from: https://zakon.rada.gov.ua/laws/show/1603-15\#Text

Verhovna Rada Ukrainy. (2019). Zakon Ukrainy № 2671-VIII Pro sotsialni posluhy. Retrieved from: https://zakon.rada.gov.ua/laws/show/2671-19\#Text

Verhovna Rada Ukrainy. (2020). Zakon Ukrainy № 2011-XII Pro sotsialnyi i pravovyi zakhyst viiskovosluzhbovtsiv ta chleniv yikh simei. Retrieved from: https://zakon.rada. gov.ua/laws/show/2011-12\#Text

Verhovna Rada Ukrainy. (2020). Zakon Ukrainy № 3551-XII Pro status veteraniv viiny, harantii yikh sotsialnoho zakhystu. Retrieved from: https://zakon.rada.gov.ua/laws/ show/3551-12\#Text 